\title{
Testicular and ovarian gonocytes from 20-day incubated chicken embryos contribute to germline lineage after transfer into bloodstream of recipient embryos
}

\author{
Mitsuru Naito ${ }^{1}$, Takeo Minematsu ${ }^{1}$, Takashi Harumi ${ }^{2}$ and Takashi Kuwana ${ }^{3}$ \\ ${ }^{1}$ Transgenic Animal Research Center and ${ }^{2}$ Animal Genome Research Unit, National Institute of Agrobiological \\ Sciences, Tsukuba, Ibaraki 305-8602, Japan and ${ }^{3}$ Laboratory of Intellectual Fundamentals for Environmental Studies, \\ National Institute for Environmental Studies, Tsukuba, Ibaraki 305-8506, Japan \\ Correspondence should be addressed to M Naito; Email: mnaito@affrc.go.jp
}

\begin{abstract}
The present study was conducted to elucidate whether testicular and ovarian gonocytes obtained from 20-day incubated chicken embryos (stage 45) have the ability to migrate to the germinal ridges and contribute to germline lineage after transfer into the bloodstream of recipient embryos. Testicular and ovarian gonocytes were first identified as relatively large cells in a population of gonadal cells. The proportions of testicular and ovarian gonocytes in the total gonadal cells were 0.94 and $0.75 \%$ respectively, recognised as chicken vasa homologue-positive cells. Then, the dissociated gonadal cells obtained from 20-day incubated embryos containing testicular or ovarian gonocytes, with or without transfection, were transferred into recipient embryos. Expression of the introduced GFP gene was observed in the gonads of 6.5-day cultured recipient embryos (stage 30) in males and females, suggesting that the transferred testicular and ovarian gonocytes have the ability to migrate to the germinal ridges and enter the gonads. Furthermore, the presence of the donor-derived DNA was detected in the gonads of 20-day cultured recipient embryos in males and females, and also in the sperm samples obtained from the hatched male putative chimaeric chickens, suggesting that the transferred testicular and ovarian gonocytes were incorporated into the germline of chimaeric embryos and chickens. It is concluded that testicular and ovarian gonocytes obtained from 20-day incubated embryos have the ability to migrate to the germinal ridges after transfer into the bloodstream of recipient embryos, enter the gonads and contribute to the germline lineage of chimaeric embryos and chickens.
\end{abstract}

Reproduction (2007) 134 577-584

\section{Introduction}

Primordial germ cells (PGCs) in chickens originate from the epiblast and locate in the central part of the area pellucida at stage X (Eyal-Giladi \& Kochav 1976). They move to the anterior region of the hypoblast, called the germinal crescent, at the primitive streak stage. Then, PGCs enter the developing blood vascular system, circulate temporarily in the bloodstream and finally migrate to the germinal ridges (Kuwana 1993). PGCs entering the testes start to divide actively after 13 days of incubation (stage 39; Hamburger \& Hamilton 1951) and differentiate into spermatogonia (Howarth 1995). PGCs entering the left ovary differentiate to form oogonia after 8 days of incubation (stage 34 ) and start to divide actively in the process of differentiating into primary oocytes. The primary oocytes subsequently enter the meiotic prophase by 16 days of incubation (stage 42; Ukeshima \& Fujimoto 1991). The number of primary oocytes peaks at around 17 days of incubation (stage 43) and then rapidly decreases (Hughes 1963). Differentiation of the primary oocytes then ceases temporarily at the meiotic prophase. In contrast, the right ovary ceases to develop further at 7 days of incubation (stage 31) and degenerates during embryonic development.

PGCs circulating in the bloodstream have the ability to migrate to the germinal ridges of embryos, which makes it possible to transfer PGCs between embryos and produce germline chimaeric chickens (Tajima 2002, Naito 2003a, 2003b, 2003c). Interestingly, PGCs isolated from embryonic blood can migrate to the germinal ridges after transfer into the stage $X$ blastoderm (Naito et al. 2004). Furthermore, PGCs isolated from the gonads of 5-day incubated embryos (stage 27) can migrate to the germinal ridges after transfer into the bloodstream of recipient embryos and enter the germline (Chang et al. 1997, Tajima et al. 1998). In general, it is thought that male PGCs retain the ability to migrate to the germinal ridges up to 12-13 days of incubation (stages 38 and 39) and that female PGCs retain the migratory ability up to 7 days of incubation (Howarth 1995). Recently, Minematsu et al. 


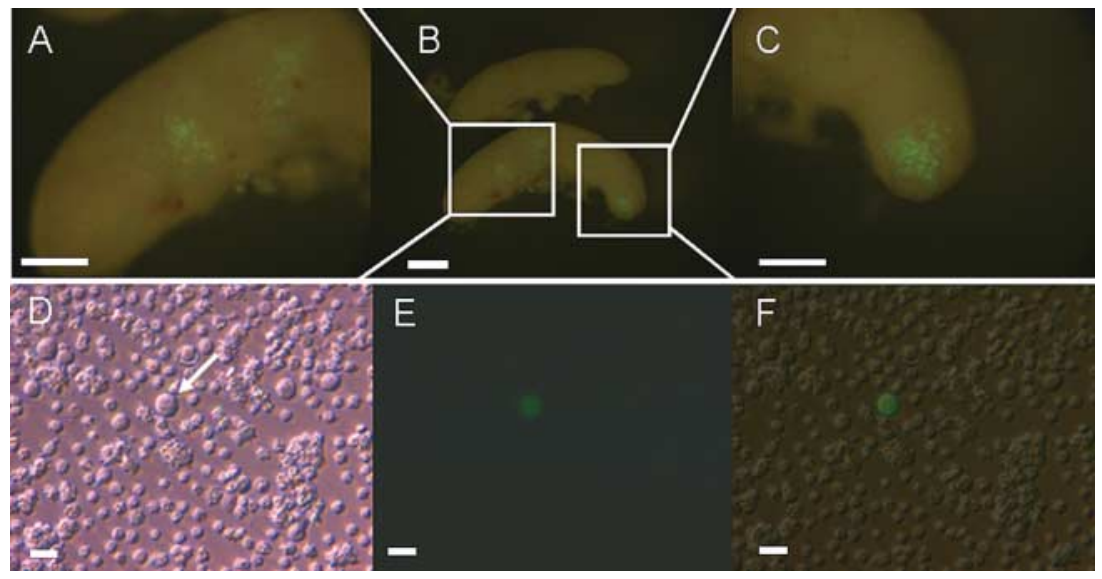

Figure 1 Identification of gonocytes in a cell population derived from testis of 20-day incubated embryos. PGCs isolated from embryonic blood were transfected in vitro by lipofection, transferred to recipient embryos and cultured in host eggshells up to day 20 of incubation. Gonocytes were identified by detecting the GFP gene expression in the dissociated cell population. Photograph (B) shows testes expressing GFP gene and high-power magnification of boxed areas in (B) are shown in (A) and (C) respectively. Scale bars represent $0.5 \mathrm{~mm}$. Photograph (D) shows dissociated cells from the left testis, photograph (E) shows a GFP-positive cell, and merged photograph of (D) and (E) is shown in (F). Arrow (D) indicates a gonocyte. Scale bars represent $20 \mu \mathrm{m}$.
(2004) reported the presence of gonocytes retaining the migratory ability in the gonads of embryos up to 20.5 days of incubation (stage 45) and also germ cells (GCs) in the testes or ovaries of sexually matured chickens. Differentiation into the functional gametes of these migrated PGCs, gonocytes or GCs in the recipient gonads, however, has not been examined. Long-term tracing of the donor cells in recipient embryos has now become possible by detecting the single nucleotide polymorphism (SNP) using compatible populations of donors and recipients (Harumi et al. 2004). Germline chimaeras can thus be identified by analysing the DNA extracted from the gonads of developing embryos or from the sperm samples of adult chickens before test cross.

The spermatogonia population in the testes contains stem cells (Kanatsu-Shinohara et al. 2003). Culture of these stem cells provides a novel method for manipulating chicken germline in vitro. To manipulate these germline cells, one must assess the migratory ability and subsequently differentiate germline cells into functional gametes after transfer into the bloodstream of recipient embryos. The present study was carried out to examine whether testicular and ovarian gonocytes obtained from 20-day incubated embryos (stage 45) have the ability to migrate to the germinal ridges and contribute to the germline lineage after transfer into the bloodstream of recipient embryos.

\section{Results}

\section{Identification of testicular and ovarian gonocytes}

Dissociated gonadal cells derived from 20-day incubated embryos contain testicular or ovarian gonocytes as well as somatic cells. In order to identify testicular and ovarian gonocytes as living cells, transfected PGCs were transferred into recipient embryos and cultured. GFP gene expression was observed in limited areas of the chimaeric testes and ovary (Figs $1 \mathrm{~A}-\mathrm{C}$ and $2 \mathrm{~A}$ and B) of 20-day cultured embryos. After dissociation of gonadal cells, GFP-positive cells were identified as gonocytes in testicular and ovarian cells (Figs $1 \mathrm{D}-\mathrm{F}$ and $2 \mathrm{C}-\mathrm{E}$ ), and they were recognised to be relatively large cells compared with other somatic cells. Testicular and ovarian gonocytes obtained from 20-day incubated embryos were also identified by immunostaining and recognised as chicken vasa homologue $(\mathrm{CVH})$-positive cells (Fig. 3A and B). The proportion
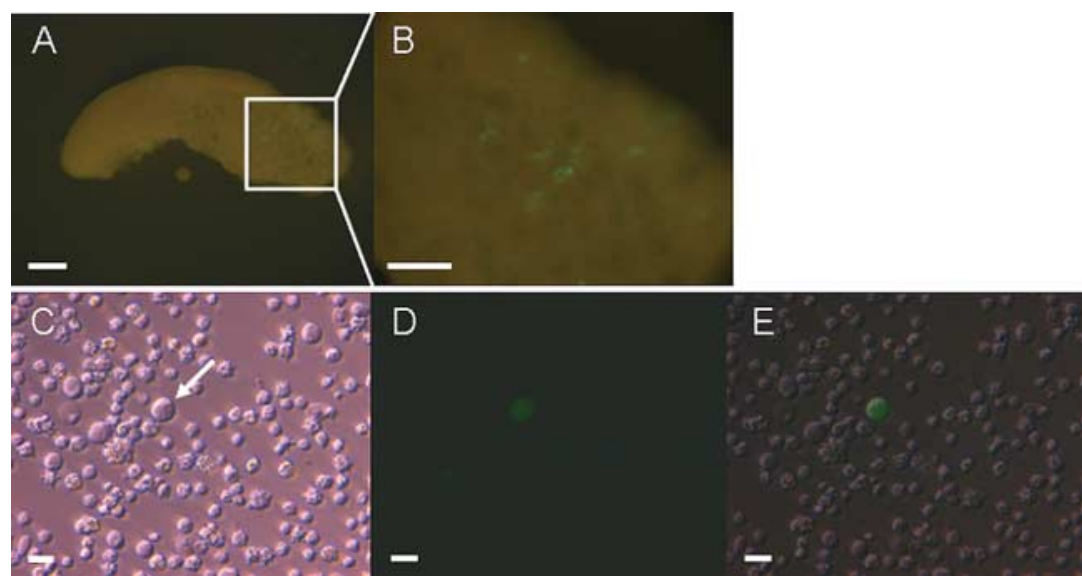

Figure 2 Identification of gonocytes in a cell population derived from left ovary of 20-day incubated embryos. PGCs isolated from embryonic blood were transfected in vitro by lipofection, transferred to recipient embryos and cultured in host eggshells up to day 20 of incubation. Gonocytes were identified by detecting the GFP gene expression in the dissociated cell population. Photograph (A) shows left ovary expressing GFP gene, and high-power magnification of boxed areas in (A) is shown in (B). Scale bars represent $0.5 \mathrm{~mm}$. Photograph (C) shows dissociated cells from the left ovary; photograph (D) shows a GFP-positive cell; and merged photograph of $(\mathrm{C})$ and $(\mathrm{D})$ is shown in (E). Arrow (C) indicates a gonocyte. Scale bars represent $20 \mu \mathrm{m}$. 

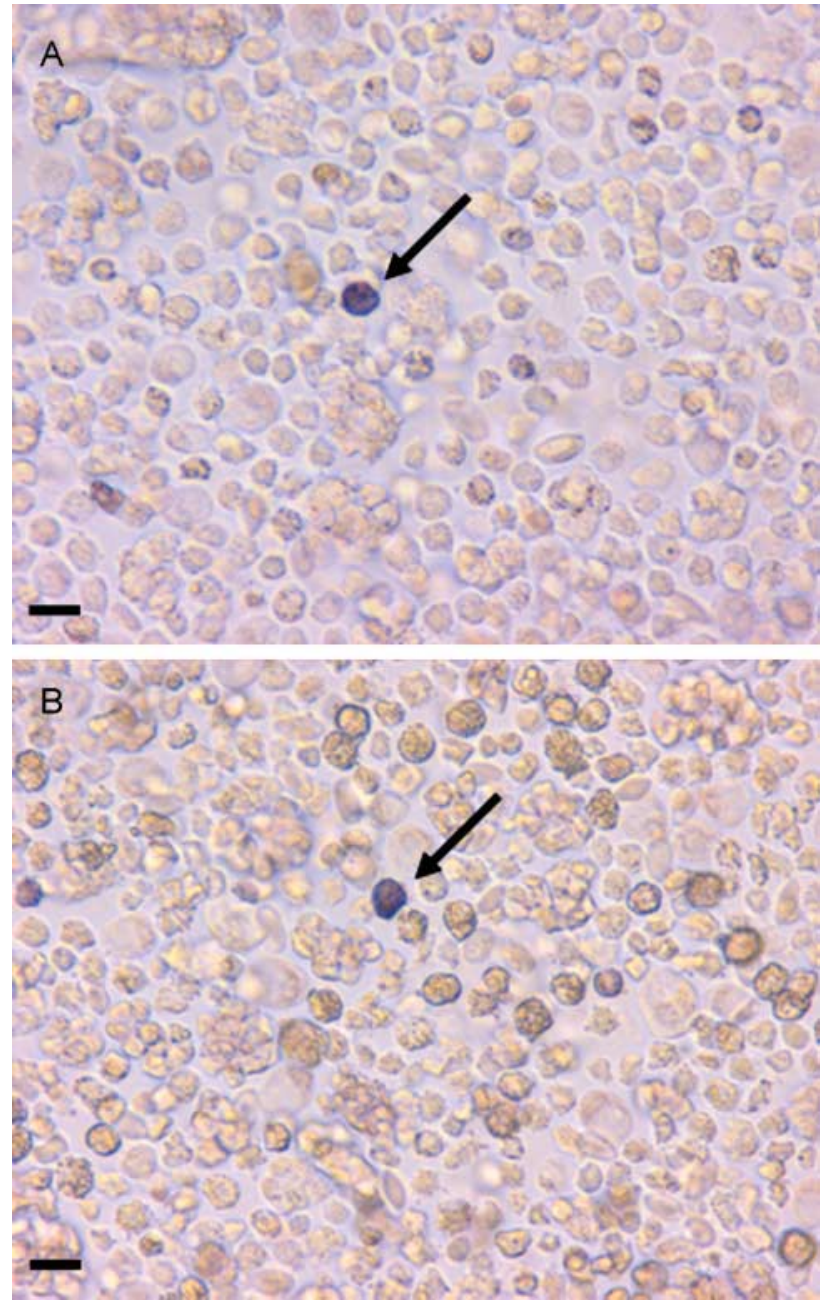

Figure 3 Gonocytes obtained from left testis (A) or left ovary (B) of 20-day incubated embryos. Arrows indicate testicular or ovarian gonocyte identified by immunostaining detected $\mathrm{CVH}$-positive cells. Scale bars represent $20 \mu \mathrm{m}$.

of gonocytes in the male and female gonadal cell populations were $0.94 \%(60 / 6400)$ and $0.75 \%$ $(55 / 7320)$ respectively.

\section{GFP gene expression in manipulated embryos}

Dissociated gonadal cells containing testicular or ovarin gonocytes derived from 20-day incubated embryos were transfected in vitro and then transferred to recipient embryos. Expression of the introduced GFP gene was examined in the gonads of 6.5-day cultured recipient embryos. The GFP gene expression was clearly observed in the gonads of embryos in which transfected testicular gonocytes (Fig. 4A-C) or ovarian gonocytes (Fig. 4D-F) had been transferred. The GFP gene was mainly expressed in the left gonads of both chimaeric embryos. The rates of GFP gene expressing embryos in the gonads were $66.7 \%(10 / 15)$ in embryos with transfected
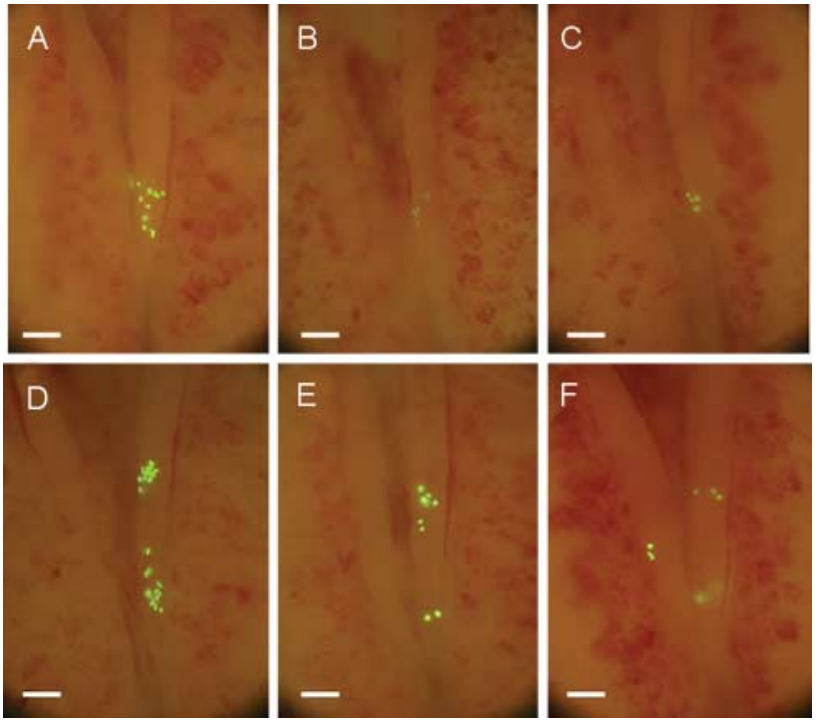

Figure 4 Expression of GFP gene in the gonads of 6.5-day incubated embryos. Gonadal cells derived from left testis or left ovary of 20-day incubated embryos were transfected in vitro by lipofection and then transferred to recipient embryos. The manipulated embryos were cultured in host eggshells for 4 days. GFP-positive cells were observed mainly in left gonads of embryos. (A-C) Embryos transferred testicular gonocytes. (D-F) Embryos transferred ovarian gonocytes. Scale bars represent $0.5 \mathrm{~mm}$.

testicular gonocytes and $72.7 \%(16 / 22)$ in embryos with transfected ovarian gonocytes.

\section{Detection of donor-derived D-loop mitochondrial DNA in gonads of recipient embryos}

To further confirm the incorporation of the transferred testicular and ovarian gonocytes into the recipient gonads, recipient embryos (White Leghorn; WL), which were transferred gonadal cells of 20-day incubated embryos (Barred Plymouth Rock; BPR), were cultured up to 17 days. Viabilities of embryos were $82.6 \%$ $(19 / 23)$ when testicular cells were transferred and $69.7 \%(23 / 33)$ when ovarian cells were transferred (Table 1). DNA samples from the gonads and blood (as a control) were analysed for the presence of the donorderived D-loop region of the mitochondrial DNA by PCR. Donor-derived DNA was detected in all the DNA samples from the gonads of embryos in both the sameand mixed-sex chimaeric embryos, whereas the donorderived DNA were detected in none of the DNA samples from the blood (Fig. 5, Table 1).

\section{Detection of donor-derived D-loop mitochondrial DNA in sperms of putative chimaeric chickens and test mating}

To examine the incorporation of the transferred testicular and ovarian gonocytes in the germline of recipient 
Table 1 Presence of donor-derived mitochondrial DNA in gonads of 17-day cultured recipient embryos.

\begin{tabular}{|c|c|c|c|c|c|}
\hline \multirow[b]{2}{*}{ Donor cells containing } & \multirow{2}{*}{$\begin{array}{c}\text { Number of embryos } \\
\text { treated }\end{array}$} & \multicolumn{2}{|c|}{ Number of surviving embryos at day 17} & \multicolumn{2}{|c|}{$\begin{array}{c}\text { Number of embryos with donor-derived } \\
\text { mitochondrial DNA }\end{array}$} \\
\hline & & Total & (Males, females) & Gonads & Blood \\
\hline Testicular gonocytes & 23 & $19(82.6 \%)$ & $(7,12)$ & $19(100 \%)$ & $0(0 \%)$ \\
\hline Ovarian gonocytes & 33 & $23(69.7 \%)$ & $(10,13)$ & $23(100 \%)$ & $0(0 \%)$ \\
\hline
\end{tabular}

embryos, the manipulated embryos (White Leghorn; WL) which were transferred gonadal cells of 20-day incubated embryos (Barred Plymouth Rock; BPR) were cultured until hatching. The hatching rates were $32.3 \%$ (10/32) when testicular cells were transferred and $45.7 \%$ (16/35) when ovarian cells were transferred. When the putative chimaeric chickens became mature, DNA samples from the sperm and blood (as a control) were collected from the males and were analysed for the presence of the donor-derived D-loop region of the mitochondrial DNA by PCR. Donor-derived DNA was detected in all DNA samples obtained from the sperm of six males examined (four males transferred testicular gonocytes and two males transferred ovarian gonocytes), whereas no DNA samples from the blood contained the donor-derived DNA in all males (Fig. 6).

Test mating was carried out to examine whether donor-derived functional gametes were produced from the putative chimaeric chickens. The test period was 36-51 weeks in males and 51-59 weeks in females. The numbers of offspring examined were 290-507 (total 2106) in each male and 90-272 (total 1400) in each female. So far, no donor-derived offspring have been obtained from the putative chimaeric chickens in six males and seven females tested. The progeny test is still in progress.

\section{Discussion}

In the present study, testicular and ovarian gonocytes in the gonads of 20-day incubated embryos were first identified by detecting the transfected PGC-derived cells in the chimaeric gonads and also by detecting $\mathrm{CVH}$ positive cells. PGCs isolated from embryonic blood were transfected in vitro and then transferred to recipient embryos. Some of the gonocytes were still recognised as GFP-positive cells in the chimaeric gonads of 20-day incubated embryos. After dissociation of the gonadal cells, testicular and ovarian gonocytes were clearly identified as GFP-positive cells, and it was confirmed that they were relatively large cells in the gonadal cell populations. Testicular and ovarian gonocytes were also detected as $\mathrm{CVH}$-positive cells, and the proportions of the testicular and ovarian gonocytes were 0.94 and $0.75 \%$ respectively in the gonadal cell populations.

The results of the gonadal cell transfer experiment show that testicular and ovarian gonocytes obtained from 20-day incubated embryos have the ability to migrate to the germinal ridges of recipient embryos, enter the gonads and contribute to the germline lineage after transfer into the bloodstream of recipient embryos. The introduction of testicular and ovarian gonocytes into the recipient gonads and germline was confirmed by detecting the expression of introduced GFP gene and the presence of donor-derived mitochondrial DNA in the gonads of developing recipient embryos. The contribution of the donor cells to the recipient germline lineage was also confirmed by detecting the donorderived mitochondrial DNA in the sperm samples of the putative chimaeric chickens. It could not be confirmed, however, that the transferred testicular and ovarian gonocytes differentiated into functional gametes, because no donor-derived offspring have so far been obtained from the putative chimaeric chickens in males and females.

Mixed-sex germline chimaeric chickens produced by the transfer of different-sex PGCs isolated from the blood of 2.5-day incubated embryos can hardly generate donor-derived offspring (Naito et al. 1999). In the present study, ovarian gonocytes were transferred into

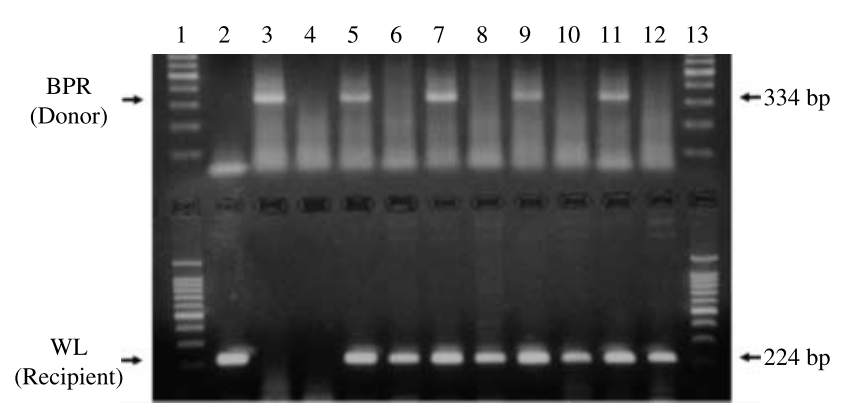

Figure 5 PCR analysis of chimaeric chicken embryos produced by the transfer of gonadal cells obtained from the left testis or left ovary of 20-day incubated embryos (BPR, Barred Plymouth Rock) into the bloodstream of stages 14 and 15 recipient embryos $(\mathrm{WL}$, White Leghorn). Donor cells contained testicular or ovarian gonocytes as well as somatic cells. DNA was extracted from the gonads of 17-day cultured embryos. Presence of donor-derived cells (BPR) was detected by the single nucleotide polymorphism in the D-loop region of the mitochondrial DNA in BPR and WL used in this study. Lanes 1 and 13, molecular size marker; lane 2, positive control (gonads, WL); lane 3, positive control (gonads, BPR); lane 4, negative control (water); lanes $5-12$, gonads and blood cells isolated from embryos manipulated (lanes 5 and 9, testes; lanes 7 and 11, left ovary; lanes 6, 8, 10 and 12, blood cells). Lanes $5-8$, donor cells were testicular gonocytes. Lanes 9-12, donor cells were ovarian gonocytes. 


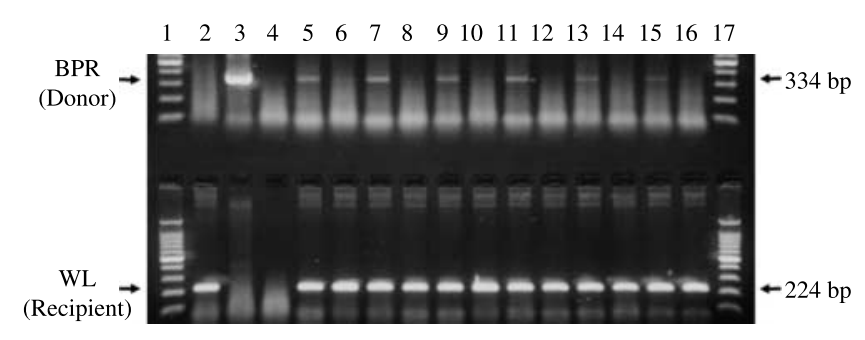

Figure 6 PCR analysis of sperm and blood cells obtained from chimaeric embryos produced by the transfer of gonadal cells obtained from the left testis or left ovary of 20-day incubated embryos (BPR, Barred Plymouth Rock) into the bloodstream of stages 14 and 15 recipient embryos (WL, White Leghorn). Donor cells contained testicular or ovarian gonocytes as well as somatic cells. DNA was extracted from the sperm and blood cells. Presence of donor-derived cells (BPR) was detected by the single nucleotide polymorphism in the D-loop region of the mitochondrial DNA in BPR and WL used in this study. Lanes 1 and 13, molecular size marker; lane 2, positive control (WL); lane 3, positive control (BPR); lane 4, negative control (water); lanes 5-12, sperm and blood cells obtained from chimaeric chickens produced by the transfer of testicular gonocytes (lanes 5, 7, 9 and 11, sperm; lanes 6, 8, 10 and 12, blood cells). Lanes 13-16 show sperm and blood cells obtained from chimaeric chickens produced by the transfer of ovarian gonocytes (lanes 13 and 15, sperm; lanes 14 and 16 , blood cells).

male recipient embryos, and these donor cells entering the recipient gonads were also incorporated into recipient germline. This is, to our knowledge, the first observation of ovarian gonocytes that could be incorporated into male germline. When female PGCs isolated from the blood of 2.5-day incubated embryos were transferred into male recipient embryos, the female PGCs entered the recipient germline and differentiated normally up to the round spermatid stage through the first and second meiotic divisions (Tagami et al. 2007). Further differentiation of the W-chromosome-bearing spermatids into spermatozoa (spermiogenesis) was hardly completed (Naito et al. 1999, 2001, Tagami et al. 2007), but the Z-chromosome-bearing spermatids completed spermiogenesis. The transferred ovarian gonocytes in the present study probably differentiated normally into spermatids, but only Z-chromosomebearing spermatozoa were produced and detected as donor-derived mitochondrial DNA in the sperm samples of the mixed-sex germline chimaeric chickens.

Spermatogonia transplanted into the seminiferous tubules of recipient testes differentiated normally and reportedly gave rise to viable progenies in mice (Brinster \& Zimmemann 1994). Also in chickens, testicular cells (spermatogonia and differentiated spermatogenic cells) transplanted into recipient testes of juvenile or adult chickens were incorporated into the germline and produced viable offspring (Lee et al. 2006). The frequency of donor-derived offspring from the chimaeric chickens was, however, very low (0.4-0.9\%), suggesting that few, if any, testicular cells participate in the spermatogenesis in recipient testes. When gonadal cells of embryos incubated for 5-7 days (stages 27-31) were transferred into the bloodstream of recipient embryos, germline transmission rates of donor-derived gametes were only up to $27.6 \%$ (Chang et al. 1997, Tajima et al. 1998, Park et al. 2003) when compared with up to $97.6 \%$ for PGCs isolated from the blood of 2.5-day incubated embryos (Naito et al. 1994a,1994b, 1998a, $1998 b, 1999)$. PGCs that entered the gonads gradually lost their ability to migrate to the germinal ridges, and their incorporation rate in the recipient germline decreased when they were transferred to recipient embryos. This evidence notwithstanding, the presence of migratory GCs in the testes or ovary of adult chickens was reported (Minematsu et al. 2004). The characteristics of these migratory cells in adult testes or ovary should be examined in future.

It is confirmed that germline stem cells are present in the population of spermatogonia in the testes of adult mice, and the genetic manipulation of germline cells via cultured germline stem cells is now being explored (Kanatsu-Shinohara et al. 2003, 2006). In chickens, germline stem cell-like cells are present in a population of spermatogonia (Jung et al. 2007). The population of testicular gonocytes manipulated in the present study would, thus, contain the germline stem cells. If these germline stem cells could be isolated and cultured in vitro, a novel method for germline manipulation could be devised in chickens. A technique must be developed to produce viable offspring efficiently from the germline stem cells when they are established.

It is concluded that testicular and ovarian gonocytes obtained from 20-day incubated embryos have the ability to migrate to the germinal ridges after transfer into the bloodstream of recipient embryos, and they could enter the gonads and contribute to the germline lineage of chimaeric embryos and chickens.

\section{Materials and Methods}

\section{Fertilised eggs and animal care}

Fertilised eggs of White Leghorn (WL) and Barred Plymouth Rock (BPR) chickens were obtained by artificial insemination. $\mathrm{WL}$ and BPR populations are maintained at the National Institute of Livestock and Grassland Science. All animals received humane care as outlined in the Guide for the Care and Use of Experimental Animals (National Institute of Agrobiological Sciences, Animal Care Committee).

\section{Preparation of PGCS}

Fertilised eggs of BPR were incubated at $38^{\circ} \mathrm{C}$ for about $53 \mathrm{~h}$ in a forced-air incubator (P-008B Bio-type; Showa Furanki, Saitama, Japan). Blood was collected from the dorsal aorta of embryos at stages 13-15 using a fine glass micropipette. PGCs were concentrated by the Nycodenz density gradient centrifugation method (Zhao \& Kuwana 2003, Naito et al. 2004). Briefly, the collected blood was pooled, washed and dispersed in a $400 \mu \mathrm{l} \mathrm{KAv-1}$ medium (Kuwana et al. 1996). Five millilitres 
of $11 \%$ Nycodenz solution was placed in a $50 \mathrm{ml}$ tube (Cat. No. 2070, Becton Dickerson, Franklin Lakes, NJ, USA), and $5 \mathrm{ml}$ of $5.5 \%$ Nycodenz solution and subsequently $400 \mu \mathrm{l}$ blood solution were overlaid. The tube was centrifuged at $400 \mathrm{~g}$ for $15 \mathrm{~min}$ and $10 \mathrm{ml}$ of the PGC-rich solution was recovered from the top and washed with $\mathrm{KAv}-1$ medium. Then, a second purification was carried out in the same manner.

\section{Transfection of PGCs}

Transfection of PGCs was carried out by lipofection using cationic lipids (Cat. No. 11668-027, Lipofectamine2000; Invitrogen). Six microlitres of Lipofectamine2000 solution were first diluted with $50 \mu \mathrm{l}$ Opti-MEM I reduced-serum medium (Cat. No. 31985-062; Invitrogen) and incubated for $5 \mathrm{~min}$ at room temperature $\left(25^{\circ} \mathrm{C}\right)$ in a $5 \mathrm{ml}$ polystyrene culture tube (Cat. No. 2003; Becton Dickerson). Two micrograms (2 $\mu \mathrm{l})$ of plasmid DNA (pbAEGFP; GFP gene under the control of chicken $\beta$-actin gene promoter) were added in the tube, mixed gently and incubated for $20 \mathrm{~min}$ at room temperature. The PGCs (about 4000 cells) dispersed in a $400 \mu \mathrm{KAv}-1$ medium were added in the tube, mixed gently and incubated for $5 \mathrm{~h}$ at $37^{\circ} \mathrm{C}$. The transfection efficiency by this method is usually about $30 \%$ (Naito et al. 2007). The transfected PGCs were then washed twice with KAv-1 medium, dispersed in a $60 \mu \mathrm{l}$ fresh KAv-1 medium and placed in a plastic dish.

\section{Preparation of recipient embryos and transfer of donor cells}

Recipient embryos of WL were cultured in host eggshells at $38^{\circ} \mathrm{C}$ for about $53 \mathrm{~h}$ as described by Naito et al. (1990). When the embryos reached stages 14 and 15, 500 donor PGCs were picked up by a fine glass micropipette and injected into the bloodstream of recipient embryos. The manipulated embryos were cultured in host eggshells at $37.8^{\circ} \mathrm{C}$ for an additional 4-18 days (Perry 1988, Naito et al. 1990).

\section{Identification of testicular and ovarian gonocytes}

Testes or left ovary were removed from the embryos in which transfected PGCs had been transferred. They were washed with Dulbecco's PBS without $\mathrm{Ca}^{2+}$ and $\mathrm{Mg}^{2+}$ (DPBS(-), Cat. No. 28-103-05 FN; Dainippon Pharmaceutical, Osaka, Japan), cut into small pieces and treated with trypsin for $20 \mathrm{~min}$ at $37^{\circ} \mathrm{C}$. Then, the cells were dissociated by pipetting, washed with KAv-1 medium and dispersed in $200 \mu \mathrm{K} K \mathrm{~K}-1$ medium. The dispersed cells were observed under an inverted fluorescence microscope (DMIRE2; Leica Microsystems, Tokyo, Japan) and testicular and ovarian gonocytes were identified as GFP-positive cells.

Testicular and ovarian gonocytes were also identified by immunostaining. The dissociated testicular and ovarian cells were fixed by $4 \%$ paraformaldehyde (163-20145; Wako Pure Chem., Osaka, Japan) for $1 \mathrm{~h}$. After washing with DPBS(-), blocking was carried out with Blocking One (03953-95; Nakalai Tesque, Kyoto, Japan) for $1 \mathrm{~h}$. The cells were then incubated with CVH antibodies (Tsunekawa et al. 2000) for $1 \mathrm{~h}$. After washing with DPBS $(-)$, the cells were incubated with alkaline phosphatase-labelled goat anti-rabbit immunoglobulin (SAB1005; Open Biosystems, Huntsville, AL, USA) for 30 min. The cells were then washed with DPBS $(-)$, incubated with 5-bromo-4-chloro-3-indoxyl phosphate/nitro blue tetrazolium chloride substrate (K0598, Dako Cytomation, Glostrup, Denmark) for 2-3 min and washed with distilled water. The treated cells were observed using an inverted microscope.

\section{Preparation of gonadal cell populations and chimaera production}

Left testis or left ovary was removed from 20-day incubated embryos. They were washed with DPBS $(-)$, cut into small pieces and treated with trypsin containing $200 \mathrm{U}$ DNase I (2210A, Takara Bio Inc., Shiga, Japan) for $20 \mathrm{~min}$ at $37^{\circ} \mathrm{C}$. The collected gonadal cells were then washed with KAv-1 medium and dispersed in $400 \mu \mathrm{K} \mathrm{KAv-1}$ medium. The gonadal cell populations (500-2000 cells) containing testicular and ovarian gonocytes, with or without transfection of GFP gene, were picked up by a fine glass micropipette and transferred to the bloodstream of recipient embryos. The manipulated embryos were cultured in host eggshells for 4-15 days or until hatching.

\section{Detection of GFP gene expression in gonads of embryos}

Embryos cultured for 4 days (stage 30) after the injection of transfected gonadal cell populations containing testicular and ovarian gonocytes were removed from the yolk, washed with DPBS ( - ) and the gonads were exposed. Expression of the GFP gene was detected under a fluorescence microscope (MZFL-III, Leica Microsystems).

\section{Detection of donor-derived D-loop mitochondrial DNA in gonads of recipient embryos}

In order to detect the donor-derived cells in the gonads of recipient embryos, the recipient gonads and also the blood (as a control) were analysed for the presence of the donor-derived D-loop region of the mitochondrial DNA.

Blood (about $100 \mu \mathrm{l}$ ) was collected from the embryos cultured for 15 days (stage 43) after the injection of gonadal cells, then gonads were collected and washed with DPBS $(-)$. DNA was extracted from the blood and gonads using a DNA extraction kit (SepaGene, Sanko Junyaku, Tokyo, Japan) according to the manufacturer's instructions. The extracted DNA was dissolved in distilled water at a concentration of $100 \mathrm{ng} / \mu \mathrm{l}$, and PCR analysis was then carried out on $200 \mathrm{ng}$ DNA samples to detect the presence of the donor-derived D-loop region of the mitochondrial DNA.

In the DNA sequences of chicken mitochondrial DNA of the D-loop region (DNA database accession number: AB091008), the 686th base is fixed as ' $A$ ' in the WL and as ' $G$ ' in the BPR used in this study (Harumi et al. 2004). In order to detect this SNP by $\mathrm{PCR}$, mismatch-containing primers were designed. The sequences of the primers were 5-2C: 5 '-TGG GGC TTC TTC ACA GGT CA-3' and DS7: 5'-CGA CAA GCA TTC ACTAAATAG CAC C-3' for detecting the $\mathrm{WL}$; and 5-3C: $5^{\prime}$-CCG CAC CCG CAC TGT GAA GGC C- $3^{\prime}$ and DS3: 5' $5^{\prime}$ CCA TTT GGT TAT GCT 
CGC CGT ATC-3' for detecting the BPR (Harumi et al. 2004). PCR mixture was prepared using Takara Ex Taq kit (PR001, Takara Bio Inc.) and the reaction was carried out using GenAmp PCR system 9700 (Applied Biosystems Japan, Tokyo, Japan). After an initial denaturation step of $94{ }^{\circ} \mathrm{C}$ for $2 \mathrm{~min}, 40$ cycles were carried out; DNA was denatured at $94{ }^{\circ} \mathrm{C}$ for $30 \mathrm{~s}$, annealed at $62{ }^{\circ} \mathrm{C}$ for $30 \mathrm{~s}$ and extended at $72{ }^{\circ} \mathrm{C}$ for $1 \mathrm{~min}$. The reactions were then incubated at $72{ }^{\circ} \mathrm{C}$ for $5 \mathrm{~min}$. After amplification, $5 \mu \mathrm{l}$ of the PCR products were separated on a $2 \%$ agarose gel, and the bands (WL: $224 \mathrm{bp}, \mathrm{BPR}: 334 \mathrm{bp}$ ) were visualised under u.v. light after ethidium bromide staining.

\section{Test mating}

Chicks hatched were raised until sexual maturity in which gonadal cell populations containing testicular or ovarian gonocytes had been transferred at the embryonic stage. Semen and blood were collected from the male putative chimaeric chickens, DNA was extracted from the collected sperms and blood cells and analysed for the presence of the donor-derived D-loop region of the mitochondrial DNA.

Both male and female mature putative chimaeric chickens were mated with BPR using artificial insemination, and the feather colour of their offspring was recorded. BPR are homozygous recessive $(i / i)$ at the autosomal pigment inhibitor gene and the chick feathers are black, while WL are homozygous dominant $(I / I)$ and their feathers are white. Black offspring $(i / i)$ indicate that the chicks were derived from the donor cells (BPR), while white offspring (I/i) show their derivation from the recipient cells (WL).

\section{Acknowledgements}

The authors would like to thank the staff of the Poultry Management Section of the National Institute of Livestock and Grassland Science for taking care of the birds and providing the fertilised eggs. This study was supported by the Special Fund from the National Institute of Agrobiological Sciences (to $M N$ ), the Special Coordination Fund from the Ministry of Education, Culture, Sports, Science and Technology of the Japanese Government (to $\mathrm{M} \mathrm{N}$ and $\mathrm{T} \mathrm{K}$ ) and a Grant-in-Aid (No. 16380193) from the Japan Society for the Promotion of Science (to $\mathrm{MN}$ ). The authors declare that there is no conflict of interest that would prejudice the impartiality of this scientific work.

\section{References}

Brinster RL \& Zimmemann JW 1994 Spermatogenesis following male germcell transplantation. PNAS 91 11298-11302.

Chang IK, Jeong DK, Hong YH, Park TS, Moon YK, Ohno T \& Han JY 1997 Production of germline chimeric chickens by transfer of cultured primordial germ cells. Cell Biology International 21 495-499.

Eyal-Giladi H \& Kochav S 1976 From cleavage to primitive streak formation: a complementary normal table and a new look at the first stages of the development of the chick. I. General morphology. Developmental Biology 49 321-337.

Hamburger V \& Hamilton HL 1951 A series of normal stages in the development of the chick embryo. Journal of Morphology 8 49-92.

Harumi T, Sano A, Kagami H, Tagami T, Matsubara Y \& Naito M 2004 PCR detection of single nucleotide polymorphisms in the chicken mitochondrial D-loop region. Animal Science Journal 75 503-507.
Howarth B 1995 Physiology of reproduction: the male. In Poultry Production, pp 243-270. Ed. P Hunton. Amsterdam: Elsevier.

Hughes GC 1963 The population of germ cells in the developing female chick. Journal of Embryology and Experimental Morphology 11 513-536.

Jung JG, Lee YM, Park TS, Park SH, Lim JM \& Han JY 2007 Identification, culture, and characterization of germline stem cell-like cells in chicken testes. Biology of Reproduction 76 173-182.

Kanatsu-Shinohara M, Ogonuki N, Inoue K, Miki H, Ogura A, Toyokuni S \& Shinohara T 2003 Long-term proliferation in culture and germline transmission of mouse male germline stem cells. Biology of Reproduction 69 612-616.

Kanatsu-Shinohara M, Ikawa M, Takehashi M, Ogonuki N, Miki H, Inoue K, Kazuki Y, Lee J, Toyokuni S, Oshimura M, Ogura A \& Shinohara T 2006 Production of knockout mice by random or targeted mutagenesis in spermatogonial stem cells. PNAS 103 8018-8023.

Kuwana T 1993 Migration of avian primordial germ cells toward the gonadal anlage. Development, Growth and Differentiation 35 237-243.

Kuwana T, Hashimoto K, Nakanishi A, Yasuda Y, Tajima A \& Naito M 1996 Long-term culture of avian embryonic cells in vitro. International Journal of Developmental Biology 40 1061-1064.

Lee YM, Jung JG, Kim JN, Park TS, Kim TM, Shin SS, Kang DK, Lim JM \& Han JY 2006 A testis mediated germline chimera production based on transfer of chicken testicular cells directly into heterologous testes. Biology of Reproduction 75 380-386.

Minematsu T, Tajima A \& Kanai Y 2004 The migratory ability of gonadal germ cells in the domestic chicken. Journal of Poultry Science $\mathbf{4 1}$ 178-185.

Naito M 2003a Cryopreservation of avian germline cells and subsequent production of viable offspring. Journal of Poultry Science 40 1-12.

Naito M 2003b Development of avian embryo manipulation techniques and their application to germ cell manipulation. Animal Science Journal 74 157-168.

Naito M 2003c Genetic manipulation in chickens. World's Poultry Science Journal 59 375-385.

Naito M, Nirasawa K \& Oishi T 1990 Development in culture of the chick embryo from fertilized ovum to hatching. Journal of Experimental Zoology 254 322-326.

Naito M, Tajima A, Yasuda Y \& Kuwana T 1994a Production of germline chimeric chickens, with high transmission rate of donor-derived gametes, produced by transfer of primordial germ cells. Molecular Reproduction and Development 39 153-161.

Naito M, Tajima A, Tagami T, Yasuda Y \& Kuwana T 1994b Preservation of chick primordial germ cells in liquid nitrogen and subsequent production of viable offspring. Journal of Reproduction and Fertility 102 321-325.

Naito M, Tajima A, Yasuda Y \& Kuwana T 1998a Donor primordial germ cell-derived offspring from recipient germline chimaeric chickens: absence of long term immune rejection and effects on sex ratios. British Poultry Science 39 20-23.

Naito M, Sakurai M \& Kuwana T 1998b Expression of exogenous DNA in the gonads of chimaeric chicken embryos produced by transfer of primordial germ cells transfected in vitro and subsequent fate of the introduced DNA. Journal of Reproduction and Fertility 113 137-143.

Naito M, Matsubara Y, Harumi T, Tagami T, Kagami H, Sakurai M \& Kuwana T 1999 Differentiation of donor primordial germ cells into functional gametes in the gonads of mixed-sex germline chimaeric chickens produced by transfer of primordial germ cells isolated from embryonic blood. Journal of Reproduction and Fertility 117 291-298.

Naito M, Sano A, Matsubara Y, Harumi T, Tagami T, Sakurai M \& Kuwana T 2001 Localization of primordial germ cells or their precursors in stage $X$ blastoderm of chickens and their ability to differentiate into functional gametes in opposite-sex recipient gonads. Reproduction 121 547-552.

Naito M, Sano A, Harumi T, Matsubara Y \& Kuwana T 2004 Migration of primordial germ cells isolated from embryonic blood into the gonads after transfer to stage $X$ blastoderms and detection of germline chimaerism by PCR. British Poultry Science 45 762-768.

Naito M, Minematsu T, Harumi T \& Kuwana T 2007 Intense expression of GFP gene in gonads of chicken embryos by transfecting circulating primordial germ cells in vitro and in vivo. Journal of Poultry Science $\mathbf{4 4}$ [in press]. 
Park TS, Hong YH, Kwon SC, Lim JM \& Han JY 2003 Birth of germline chimeras by transfer of chicken embryonic germ (EG) cells into recipient embryos. Molecular Reproduction and Development 65 389-395.

Perry MM 1988 A complete culture system for the chick embryo. Nature 331 70-72.

Tagami T, Kagami H, Matsubara Y, Harumi T, Naito M, Takeda K, Hanada H \& Nirasawa K 2007 Differentiation of female primordial germ cells in the male testes of chicken (Gallus gallus domesticus). Molecular Reproduction and Development 74 68-75.

Tajima A 2002 Production of germ-line chimeras and their application in domestic chicken. Avian and Poultry Biology Reviews 13 15-30.

Tajima A, Naito M, Yasuda Y \& Kuwana T 1998 Production of germline chimeras by transfer of cryopreserved gonadal primordial germ cells (gPGCs) in chicken. Journal of Experimental Zoology $\mathbf{2 8 0}$ 265-267.
Tsunekawa N, Naito M, Sakai Y, Nishida T \& Noce T 2000 Isolation of chicken vasa homolog gene and tracing the origin of primordial germ cells. Development 127 2741-2750.

Ukeshima A \& Fujimoto T 1991 A fine morphological study of germ cells in asymmetrical developing right and left ovaries of the chick. Anatomical Record 230 378-386.

Zhao DF \& Kuwana T 2003 Purification of avian circulating primordial germ cells by Nycodenz density gradient centrifugation. British Poultry Science 44 30-35.

Received 21 March 2007

First decision 3 May 2007

Revised manuscript received 21 June 2007

Accepted 10 July 2007 